SALton, M. R. J. (1953). J. gen. Microbiol. 9, 512-528.

\title{
Cell Structure and the Enzymic Lysis of Bacteria
}

\author{
By M. R. J. SALTON* \\ Department of Bacteriology, University of California, Berkeley, California
}

\begin{abstract}
SUMMARY : Untreated cells of three Gram-negative and four Gram-positive bacteria were resistant to lysis by crude and crystalline trypsin. The resistance of the Gramnegative organisms to lysis by trypsin was abolished by heating suspensions for $5 \mathrm{~min}$. at $100^{\circ}$; the rates and extent of lysis of the three organisms by crude trypsin were comparable. After maximal lysis of heated suspensions of Bacterium coli and Pseudomonas fluorescens by crude trypsin, examination of the residual material in the electron microscope showed that cell walls were the principal components. When heated suspensions of Micrococcus lysodeikticus, Bacillus megaterium and Staphylococcus aureus were incubated with crude or crystalline trypsin, slow lysis occurred and the extent of lysis was less than that observed for the Gram-negative bacteria. Electron microscopic examination of trypsin-lysed cells of $\boldsymbol{B}$. megaterium showed incomplete digestion of cytoplasmic contents. Heated and autoclaved cells of Streptococcus faecalis were resistant to digestion with trypsin.

Cell-wall suspensions of $B$. megaterium were rapidly lysed on incubation with crystalline lysozyme. Heated cells of $M$. lysodeikticus were only partially lysed by lysozyme, but the subsequent addition of trypsin resulted in a rapid dissolution of the cell bodies. Although treatment of heated $B$. megaterium cells with lysozyme resulted in turbidity increases, the enzyme completely digested the cell wall leaving coagulated protoplasmic bodies. The protoplasmic bodies were rapidly lysed by crude trypsin.
\end{abstract}

One of the most elegant methods of studying the nature and location of surface components of the bacterial cell has been that afforded by the action of certain enzymes. Capsules and other superficial layers of living bacterial cells have been removed enzymically without impairing cell viability. Enzymic degradation of type III pneumococcus polysaccharide capsule (Dubos \& Avery, 1931) and removal of the M-protein antigen from haemolytic streptococci (Lancefield, 1943) were achieved without death of the organisms. However, certain enzymes such as lysozyme (Fleming, 1922) bring about the death and rapid dissolution of susceptible bacteria. It has been known for some time that lysozyme digests a cellular component essential for the maintenance of the cell's morphological structure (Epstein \& Chain, 1940). That lysozyme effects a dissolution of the rigid cell-wall structure of Micrococcus lysodeikticus has now been established directly by studying the action of crystalline lysozyme from egg-white on the separated walls of this organism (Salton, 1952 a). At least one other enzyme system is capable of degrading cell walls of bacteria other than those attacked by lysozyme. Maxted (1948) showed that the enzymes produced by a Streptomyces sp. lysed suspensions of living $\beta$-haemolytic streptococci. Rapid lysis of turbid suspensions of separated cell walls of Strep. pyogenes by an enzyme preparation from Streptomyces sp. (obtained by Maxted's procedure) was reported by Salton (1952 $b$ ). McCarty $(1952 a, b)$ investigated the lysis of group A haemolytic streptococci

* Present address: Department of Biochemistry, Cambridge, England. 
by the extracellular enzymes of Streptomyces albus and concluded that the same enzyme fractions which were effective in lysing intact cells of group A streptococci also dissolved the isolated cell walls. Thus enzymes such as lysozyme and those of $S$. albus which are capable of lysing intact organisms, appear to have a primary lytic action upon the cell walls.

The nature and properties of the bacteriolytic substances produced by various micro-organisms have been the subject of many investigations (Waksman, 1947; Welsch, 1947; Jones, Swallow \& Webb, 1948; Muggleton \& Webb, 1952; Tai \& van Heyningen, 1951; Born, 1952). Both heat-killed bacteria and living organisms dispersed in agar have been used extensively for the detection and isolation of soil micro-organisms which produce bacteriolytic enzymes. However, it has been difficult to judge whether lytic activities were due to a primary attack on the bacterial cell walls or to other processes involving secondary lysis by proteolytic enzymes. There can be little doubt as to the importance of proteolytic enzymes in the lysis of heated bacteria. Indeed, as early as 1909, Kantorowicz reported that Gram-negative bacteria became susceptible to lysis by trypsin after they had been heated at $80^{\circ}$, whereas Gram-positive organisms were resistant to trypsin lysis even after boiling. The loss of resistance to digestion by trypsin which bacterial cells undergo on heating and the greater susceptibility of heat-killed, Gramnegative bacteria to lysis by proteolytic enzymes have never been adequately explained. Observations showing that heat-treatment resulted in rupture of the cell walls of certain bacteria (Salton \& Horne, 1951a) suggested that susceptibility of heated bacteria to lysis by proteolytic enzymes may be governed by the nature of the cell wall and the effects of heat thereon. Indeed, the cell walls of Gram-negative bacteria generally showed extensive rupture on heating at temperatures above $75^{\circ}$, whereas the walls of Gram-positive bacteria showed little or no rupture even on heating at $100^{\circ}$ (Salton, 1951). The present investigations were undertaken to determine the fate of the cell walls during enzymic lysis of heated bacteria, thereby to obtain some indication of the suitability of using heat-killed bacteria for the isolation of cell-wall decomposing micro-organisms.

\section{METHODS}

Organisms. The following organisms were used: Bacterium coli strain B; Pseudomonas fluorescens strain A 3.12; Spirillum serpens (ATCC 11330); Bacillus megaterium strain KM; Micrococcus lysodeikticus (NCTC 2665); Streptococcus faecalis (NCTC 6782) and Staphylococcus aureus (F.D.A. strain of the U.S. Department of Agriculture).

Media, growth conditions and harvesting. The three Gram-negative organisms were grown in liquid medium consisting of $(\%, w / v): 0.5$ Bacto yeast extract; 0.8 Bacto peptone; 0.1\% $\mathrm{K}_{2} \mathrm{HPO}_{4}$. B. megaterium was grown in $5 \%$ Bacto peptone broth, Staph. aureus in nutrient broth and the two other Grampositive bacteria in a liquid medium containing $2 \%$ Bacto-tryptone, $0 \cdot 1 \%$ yeast extract and $1 \%$ glucose. Flasks of medium were inoculated with $24 \mathrm{hr}$. cultures and incubated at $30^{\circ}$ with mechanical shaking for $16 \mathrm{hr}$. Cells were 
harvested from the medium by centrifugation and washed twice with distilled water.

Enzyme preparations. Crystalline egg-white lysozyme (Armour), crude trypsin, crystalline trypsin (containing c. $50 \% \mathrm{MgSO}_{4}$ ) and crystalline saltfree pancreatic ribonuclease were used. They were dissolved in $0 \cdot 1 \mathrm{M}$-phosphate buffers. Suspended material in the crude trypsin solutions was removed by centrifugation. All enzyme concentrations quoted in the results refer to final concentrations ( $w / v$ basis).

Turbidimetric study of lysis. The lytic action of the enzymes was studied with the following types of preparations: (1) untreated bacteria suspended in 0.1 M-phosphate buffers; (2) cell suspensions which had been subjected to heating at $100^{\circ}$; thick suspensions of bacteria were pipetted into large volumes of distilled water held in a water-bath at $100^{\circ}$, and the suspensions were heated at $100^{\circ}$ for $5 \mathrm{~min}$. Heated suspensions were cooled, centrifuged, and the deposits washed once with distilled water and finally suspended in 0.1 M-phosphate buffers; (3) cell walls of B. megaterium prepared by disintegration of the cells ( $10 \%$ wet-weight suspension of bacteria) in the Raytheon 9 Kc. Magnetostriction Oscillator for $10 \mathrm{~min}$. The subsequent steps in the preparation of the cell walls were those outlined by Salton \& Horne (1951 $b$ ); cell walls were finally suspended in $0.1 \mathrm{M}$-phosphate buffer.

The Klett-Summerson photoelectric colorimeter with a green filter (no. 54, spectral range $500-570 \mathrm{~m} \mu$.) was used throughout the investigation for measuring turbidities. Suspension densities of untreated bacteria, heated cells and cell walls in $0 \cdot 1 \mathrm{M}$-phosphate buffers were adjusted to give final Klett readings of c. 400, corresponding to dry weights of $c 1.5 \mathrm{mg}$. cells or cell walls $/ \mathrm{ml}$.; $9.9 \mathrm{ml}$. of each suspension were pipetted into Klett tubes which were then placed in a constant-temperature water bath at $37^{\circ}$. To these tubes $0.1 \mathrm{ml}$. of enzyme preparation in buffer or $0.1 \mathrm{ml}$. of buffer (control tubes) was added and the contents thoroughly mixed. Tubes were shaken each time before reading at various intervals in the photoelectric colorimeter.

Preparation of material for electron microscopy. Suspensions were centrifuged for $15 \mathrm{~min}$. at 10,000 r.p.m. after which the deposits were washed once with phosphate buffer and three times with distilled water on the high-speed centrifuge. The material was finally suspended in distilled water and diluted suitably for placement on electron microscope grids.

\section{RESULTS}

\section{Lysis experiments with Gram-negative bacteria}

Untreated suspensions of Bact. coli, Ps. fluorescens and Sp. serpens in phosphate buffer were incubated for $2 \mathrm{hr}$. at $37^{\circ}$ with: (1) crude trypsin, $1 \mathrm{mg} . / \mathrm{ml}$., pH $7 \cdot 6$; (2) crystalline trypsin, $100 \mu \mathrm{g} . / \mathrm{ml} ., \mathrm{pH} 7 \cdot 6$; (3) crystalline ribonuclease, $50 \mu \mathrm{g} . / \mathrm{ml}$. pH $7 \cdot 6$; (4) crystalline lysozyme concentrations of $100 \mu \mathrm{g}$. and $1 \mathrm{mg} . / \mathrm{ml}$., pH 6.2. Turbidity readings of control and enzyme-treated suspensions taken at intervals over the incubation period showed no significant differences. Addition of lysozyme (1 $\mathrm{mg}$. $/ \mathrm{ml}$.) to bacterial suspensions brought 
about agglutination of the cells. The cells could be redispersed merely by shaking the tubes, and no change in the turbidities of suspensions was observed. Agglutination of bacterial cells by lysozyme has often been encountered in the past (see Thompson, 1940).

The addition of crude or crystalline trypsin to heat-killed suspensions of Bact. coli in phosphate buffer ( $\mathrm{pH} 7 \cdot 6$ ) brought about a rapid decrease in turbidity; no such change occurred in control suspensions of heated cells. Incubation of suspensions of heated Bact. coli with crystalline ribonuclease resulted in a small (c. $5 \%$ ) but consistent decrease in turbidity within $15 \mathrm{~min}$. at $37^{\circ}$, no further change being apparent on continued incubation. The course of lysis of suspensions of heated Bact. coli by crude trypsin (1 mg./ml., $\mathrm{pH} \mathrm{7 \cdot 6}$ ), crystalline trypsin (100 $\mu \mathrm{g} . / \mathrm{ml} ., \mathrm{pH} 7 \cdot 6)$ and crystalline ribonuclease $(50 \mu \mathrm{g} . / \mathrm{ml}$, pH 7.6) is illustrated in Fig. 1. Similar lysis curves were also obtained when crude trypsin was added to suspensions of heated Ps.fluorescens and Sp. serpens. Typical results of lysis experiments with $\boldsymbol{P s}$. fluorescens and $\boldsymbol{S p}$. serpens are compared with those for Bact. coli in Table 1, where the lytic activity of trypsin is expressed as percentage lysis, i.e. percentage decrease in turbidity.

\section{Table 1. Lysis of heat-killed Gram-negative bacteria by crude trypsin} (1 mg./ml., 0.1 M-phosphate buffer, pH 7.6) at $37^{\circ}$

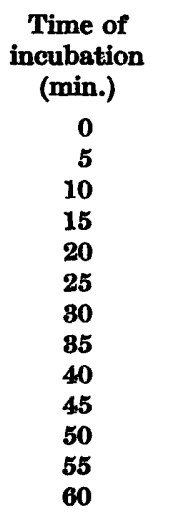

\begin{tabular}{|c|c|c|}
\hline \multicolumn{3}{|c|}{ Percentage lysis } \\
\hline Bact. coli & Ps. fluorescens & Sp. serpens \\
\hline $\mathbf{0}$ & o & 0 \\
\hline $45 \cdot 7$ & $32 \cdot 4$ & $49 \cdot 1$ \\
\hline $\mathbf{5 9} \cdot \mathbf{9}$ & $50 \cdot 5$ & $67 \cdot 9$ \\
\hline $69 \cdot 1$ & $61 \cdot 3$ & $78 \cdot 0$ \\
\hline $74 \cdot 1$ & $68 \cdot 5$ & $83 \cdot 8$ \\
\hline $76 \cdot 0$ & $78 \cdot 5$ & 86.7 \\
\hline $79 \cdot 0$ & $77 \cdot 1$ & 88.8 \\
\hline $81 \cdot 0$ & $79 \cdot 8$ & $89 \cdot 5$ \\
\hline $81 \cdot 5$ & 81.0 & 90.0 \\
\hline 82.0 & $82 \cdot 0$ & 90.8 \\
\hline 82.5 & 83.0 & 91.0 \\
\hline $82 \cdot 7$ & $\mathbf{8 3 . 9}$ & $91 \cdot 2$ \\
\hline $83 \cdot 1$ & $84 \cdot 2$ & $91 \cdot 2$ \\
\hline
\end{tabular}

When lysozyme was added to suspensions of heated Bact. coli and $\boldsymbol{P} \boldsymbol{s}$. fluorescens in phosphate buffer ( $\mathrm{pH} 6 \cdot 2$ ) at $37^{\circ}$ (final concentration of lysozyme, $1 \mathrm{mg} . / \mathrm{ml}$.) turbidity increases of 20 and $30 \%$ respectively were observed. The addition of lysozyme resulted in an immediate increase in turbidity which remained unchanged for periods of up to $12 \mathrm{hr}$. It appeared likely that the basic properties of the lysozyme, rather than its enzymic capabilities, may have been responsible for the increase in turbidities. This possibility was strengthened by the observation of a similar phenomenon when the protamine, salmine, was added to suspensions of heated Bact. coli in phosphate buffer, pH 6.2. The addition of salmine (final concentration of $1 \mathrm{mg} . / \mathrm{ml}$.) to heated Bact. coli resulted in an immediate $18 \%$ increase in turbidity, and no further change occurred on incubation for $12 \mathrm{hr}$. at $37^{\circ}$. 
The results presented in Table 1 have shown that lysis of heated suspensions of Bact. coli and Ps. fluorescens by crude trypsin was virtually completed in $1 \mathrm{hr}$. , and that the residual material accounted for 17 and $16 \%$ of the original turbidities of the suspensions. An examination of the material left after maximal clearing $\left(2 \mathrm{hr}\right.$. at $\left.37^{\circ}\right)$ of the suspensions by crude trypsin was carried out with the aid of the electron microscope. The residues from trypsin-lysed Bact. coli and Ps. fluorescens are shown in P1. 1, figs. 1 and 2, respectively. It is evident that the cell walls constitute the principal component of the residues from these organisms. In addition to the cell walls of $\boldsymbol{P}$ s. fluorescens (P1. 1, fig. 2) there would appear to be another layer of material which has also resisted digestion with trypsin.

\section{Lysis experiments woith Gram-positive bacteria}

Micrococcus lysodeikticus. Turbidity measurements performed on suspensions of unheated cells of $M$. lysodeikticus in phosphate buffer ( $\mathrm{pH} 7 \cdot 6$ ) containing either crude trypsin (1 mg./ml.), crystalline trypsin $(100 \mu \mathrm{g} . / \mathrm{ml}$.) or crystalline ribonuclease $(50 \mu \mathrm{g} . / \mathrm{ml}$.) showed no differences from control suspensions in buffer alone, when incubated for $2 \mathrm{hr}$. at $37^{\circ}$. Unheated cells of this organism in phosphate buffer ( $\mathrm{pH} \mathrm{6.2)} \mathrm{were} \mathrm{rapidly} \mathrm{lysed} \mathrm{on} \mathrm{incubation}$ with lysozyme at $37^{\circ}$. The lysis curve obtained with $5 \mu \mathrm{g}$. lysozyme $/ \mathrm{ml}$. is shown in Fig. 2 (curve 2). Lysis of $M$. lysodeikticus with a high concentration of lysozyme $(1 \mathrm{mg} . / \mathrm{ml}$.) resulted in only a $30 \%$ decrease in turbidity in $15 \mathrm{~min}$. (compared to $94 \%$ with $5 \mu \mathrm{g}$. lysozyme $/ \mathrm{ml}$.) and no further lysis occurred on incubation for $1 \mathrm{hr}$, at $37^{\circ}$.

Lysis of heated cells of $M$. lysodeikticus was investigated under the following conditions: (1) incubation with lysozyme, $5 \mu \mathrm{g} . / \mathrm{ml}$., $\mathrm{pH} \mathrm{6 \cdot 2,60} \mathrm{min.;}$ (2) treatment with lysozyme as in (1) for 30 min., followed by sedimentation of the cells, resuspension in phosphate buffer at $\mathrm{pH} 7 \cdot 6$ and incubation with crude trypsin (1 mg./ml.); (3) incubation with crude trypsin, $1 \mathrm{mg} . / \mathrm{ml}$., pH 7.6, 60 min.; (4) control suspensions in phosphate buffers, pH 6.2 and 7.6. Experiments were performed at $37^{\circ}$, and the course of lysis followed turbidimetrically. The results are presented in Fig. 2 which shows for comparison the lysis of unheated M. lysodeikticus by lysozyme. A lysis curve similar to that shown for crude trypsin (Fig. 2, curve 5) was obtained when heated cells were incubated with crystalline trypsin $(100 \mu \mathrm{g} . / \mathrm{ml}$.$) and the percentage lysis$ in $1 \mathrm{hr}$. $\left(37^{\circ}\right)$ was $26 \%$ compared to $28 \%$ with crude trypsin ( $1 \mathrm{mg} . / \mathrm{ml}$.). Incubation of heated cells with crystalline ribonuclease $(50 \mu \mathrm{g} . / \mathrm{ml} ., \mathrm{pH} 7 \cdot 6)$ resulted in a $4.5 \%$ decrease in turbidity within $15 \mathrm{~min}$. at $37^{\circ}$; no further change on incubation for $1 \mathrm{hr}$. could be detected.

Suspensions of heated $M$. lysodeikticus examined in the electron microscope before and after treatment with $5 \mu \mathrm{g}$. lysozyme $/ \mathrm{ml}$. ( $\mathrm{pH} 6 \cdot 2,37^{\circ}$ ) for $60 \mathrm{~min}$. showed that the turbidity decrease (Fig. 2, curve 3) occurred concomitantly with digestion of the cell walls.

Bacillus megaterium. Rapid dissolution of the separated cell walls of $M$. lysodeikticus by lysozyme, was demonstrated in an earlier communication (Salton, 1952a). Cell walls of B. megaterium were prepared (PI. 1, fig. 3, shows 
a typical-field of the preparation) in order to determine whether lysozyme also effected lysis of the walls of this organism. Suspensions of cell walls in phosphate buffer (pH 6.2) were incubated with lysozyme concentrations of $50 \mu \mathrm{g}$. and $100 \mu \mathrm{g} . / \mathrm{ml}$. at $37^{\circ}$, and turbidity measurements were made on control and lysozyme-treated suspensions. The progress of lysis of the walls by lysozyme is shown in Fig. 3. No change in turbidity resulted from incubation of cell walls in phosphate buffer ( $\mathrm{pH} \mathrm{7 \cdot 6)}$ with crude trypsin $(1 \mathrm{mg} . / \mathrm{ml}$.) or crystalline trypsin $\left(100 \mu \mathrm{g} . / \mathrm{ml}\right.$.) for $1 \mathrm{hr}$. at $37^{\circ}$ (Fig. 3).

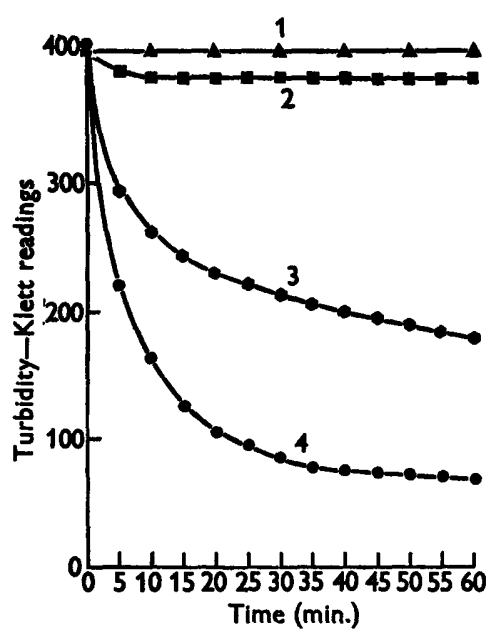

Fig. 1

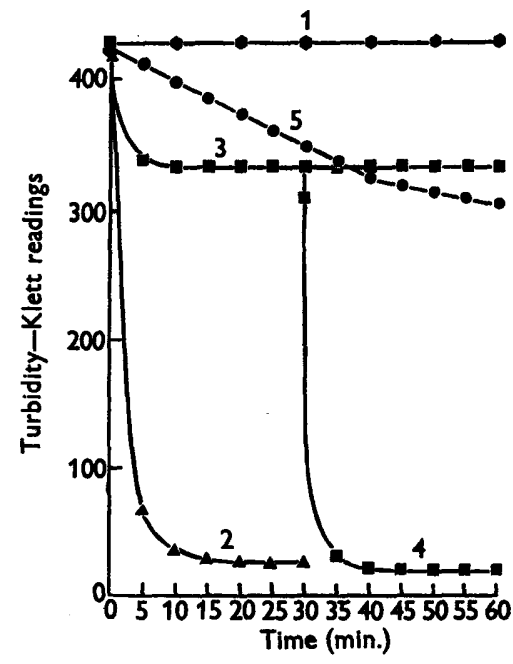

Fig. 2

Fig. 1. Lysis of heat-killed Bact. coli in $0 \cdot 1 \mathrm{~m}$-phosphate buffer at $37^{\circ}$. Curve 1 , heated cells in buffer ( $\mathrm{pH} \mathrm{7 \cdot 6)}$ alone; curve 2 , suspensions incubated with $50 \mu \mathrm{g}$. crystalline ribonuclease/ml., pH 7.6; curve 3, treatment with crystalline trypsin-100 $\mu \mathrm{g} . / \mathrm{ml} ., \mathrm{pH} 7 \cdot 6$; curve 4 , treatment with crude trypsin-1 mg./ml., pH $7 \cdot 6$.

Fig. 2. Enzymic lysis of $M$. lysodeikticus in $0.1 \mathrm{M}$-phosphate buffer at $37^{\circ}$. Curve 1 , untreated and heated cells suspended in buffer ( $\mathrm{pH}$ 's 6.2 and 7.6) alone; curve 2, lysis of unheated cells with crystalline lysozyme- $5 \mu \mathrm{g} . / \mathrm{ml}$. , pH 6.2; curve 3 , heated cells incubated with crystalline lysozyme- $-5 \mu \mathrm{g} . / \mathrm{ml}$., $\mathrm{pH} 6.2$; curve 4 , heated cells incubated with lysozyme as in curve $\mathbf{3}$ for $\mathbf{3 0}$ min., followed by sedimentation of the cells, resuspension in buffer at $\mathrm{pH} 7 \cdot 6$ and incubation with crude trypsin-1 mg./ml.; curve 5, lysis of heated cells with crude trypsin-1 $\mathrm{mg} . / \mathrm{ml}$., $\mathrm{pH} 7 \cdot 6$.

Nolysis of unheated $B$. megaterium cells was detected on incubation with crude trypsin, crystalline trypsin or crystalline ribonuclease under similar conditions to those used with other organisms. Lysozyme $(100 \mu \mathrm{g} . / \mathrm{ml}$.) rapidly lysed untreated cells as shown in Fig. 4 (curve 1) but the extent of lysis was less than that observed for $M$. lysodeikticus. The addition of crude trypsin ( $1 \mathrm{mg} . /$ ml., final concentration) to suspensions of lysozyme-lysed $B$. megaterium resulted in a rapid fall in turbidity (Fig. 4, curve 2) even at pH 6.2, a lower pH than that normally employed for tryptic digestion of proteins.

Heated suspensions of $B$. megaterium showed no lysis when treated with lysozyme (100 $\mu \mathrm{g} . / \mathrm{ml} ., \mathrm{pH} 6 \cdot 2)$. Indeed, an immediate increase in turbidity was observed and the phenomenon is illustrated in Fig. 4, curve 4. Suspensions 
of heated $B$. megaterium which had been incubated with $100 \mu \mathrm{g}$. lysozyme $/ \mathrm{ml}$. (pH 6.2) for $60 \mathrm{~min}$. at $37^{\circ}$ were examined in the electron microscope. The appearance of heated cells is shown in Pl. 1, fig. 4, Pl. 2, fig. 5, and the heated cells treated with lysozyme are illustrated in PI. 2, fig. 6. Although the turbidity of heated suspensions of $B$. megaterium was increased on incubation with lysozyme, examination in the electron microscope clearly showed the complete removal of the cell walls. Many short rods with square ends were observed in the heated $B$. megaterium preparation which had been treated with lysozyme. These 'short rods' are undoubtedly similar to the 'small bacilli' observed by Welshimer \& Robinow (1949) in both formaldehyde-treated and heated $B$. megaterium preparations, treated with lysozyme. There can be little doubt that the dissolution of the cross-walls of multicellular units of $B$. megaterium by lysozyme is responsible for $(a)$ an increase in turbidity due to the breakdown of large multicellular rods into a greater number of 'small bacilli' and $(b)$ the appearance of many short rods with characteristic square ends. Heated suspensions of $B$. megaterium were treated with $100 \mu \mathrm{g}$. lysozyme $/ \mathrm{ml}$. for $30 \mathrm{~min}$. at $37^{\circ}$ and the coagulated protoplasmic bodies corresponding to those illustrated in Pl. 2, fig. 6, were sedimented and the deposits resuspended in phosphate buffer, $\mathrm{pH} 7 \cdot 6$ and incubated with crude trypsin $(1 \mathrm{mg} . / \mathrm{ml}$.) at $37^{\circ}$. Under these conditions rapid lysis occurred and the course of lysis is shown in Fig. 4, curve 5.

Incubation of heated cells with crude trypsin resulted in a low, steady rate of lysis as shown in Fig. 4, curve 6. The extent and rate of lysis of heated $B$. megaterium with crystalline trypsin $(100 \mu \mathrm{g} . / \mathrm{ml}$.$) were comparable$ to those shown for crude trypsin (1 mg./ml.) in Fig. 4 (curve 6). The average percentage lysis in $1 \mathrm{hr}$. at $37^{\circ}$ was $10.5 \%$ for crystalline trypsin $(100 \mu \mathrm{g} . / \mathrm{ml}$.) compared to $12.1 \%$ for crude trypsin $(1 \mathrm{mg} . / \mathrm{ml}$.) and on further incubation for a total of $3 \mathrm{hr}$. at $37^{\circ}$ the percentage lysis had increased to 30 and $36 \%$ respectively. Heated cells of $B$. megaterium were examined in the electron microscope after incubation with $1 \mathrm{mg}$. crude trypsin $/ \mathrm{ml}$. in phosphate buffer (pH 7.6) for $2 \mathrm{hr}$, at $37^{\circ}$ (lysis, c. 24\%). Pl. 2, figs. 7, 8, show the typical appearance of the trypsin-lysed cells. Despite the intact appearance of the cell walls of heated cells and of unheated trypsin-lysed cells, a comparison of the heated cells (Pl. 1, fig. 4, PI. 2, fig. 5) with those incubated with crude trypsin demonstrates the loss of electron-dense material due to digestion of the protoplasmic contents.

Heat-killed $B$. megaterium incubated with crystalline ribonuclease (50 $\mu \mathrm{g} . /$ ml.) in phosphate buffer, $\mathrm{pH} \mathbf{7 \cdot 6}$, at $37^{\circ}$, consistently showed a reduction in turbidity of c. $4 \%$ within $15 \mathrm{~min}$., after which no further change in turbidity occurred on incubation for periods of up to $3 \mathrm{hr}$.

Staphylococcus aureus. Unheated cells of Staph. aureus suspended in phosphate buffer were incubated with several concentrations of lysozyme (50 $\mu \mathrm{g}$., $100 \mu \mathrm{g}$. , and $1 \mathrm{mg} . / \mathrm{ml}$., $\mathrm{pH} \mathrm{6.2}$ ) and crude trypsin (1 mg./ml., pH 7.6). No differences between turbidities of control, lysozyme-treated and crude trypsintreated suspensions could be detected on incubation for $2 \mathrm{hr}$. at $37^{\circ}$.

Lysis of heated cells was investigated by incubating suspensions with 
crude trypsin $(1 \mathrm{mg} . / \mathrm{ml}$.$) , lysozyme (100 \mu \mathrm{g} . / \mathrm{ml}$.) and lysozyme $(100 \mu \mathrm{g} . / \mathrm{ml}$, pH 6.2) followed by treatment with crude trypsin ( $1 \mathrm{mg} . / \mathrm{ml}$., pH 7.6). The results are summarized in Table 2. The enhanced trypsin lysis of heated cells of Staph. aureus that have been previously exposed to lysozyme is in agreement with the results reported by Webb (1948).

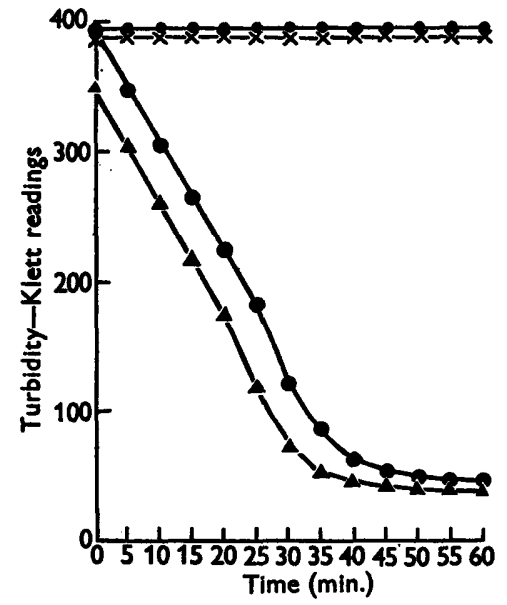

Fig. 3

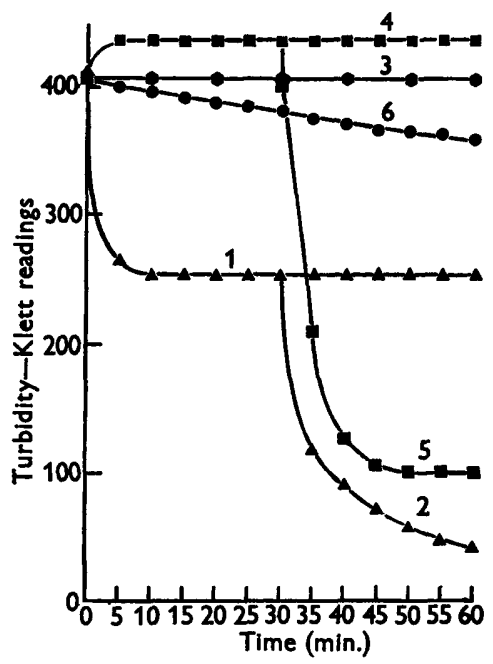

Fig. 4

Fig. 8. Lysis of $B$. megaterium cell walls in $0 \cdot 1 \mathrm{M}$-phosphate buffer at $87^{\circ}$. $-\bigcirc$, cell walls suspended in buffer (pH's 6.2 and 7.6) alone; $x-x$, cell walls incubated with crystalline trypsin-100 $\mu \mathrm{g} . / \mathrm{ml} ., \mathrm{pH} 7 \cdot 6 ; 0-0$, cell walls incubated with $100 \mu \mathrm{g}$. crystalline lysozyme/ml., pH 6.2; $\Delta-\Delta$, cell walls incubated with $50 \mu \mathrm{g}$. crystalline lysozyme/ml., pH 6.2.

Fig. 4. Enzymic lysis of $B$. megaterium in $0 \cdot 1 \mathrm{M}$-phosphate buffer at $37^{\circ}$. Curve 1 , lysis of unheated cells by crystalline lysozyme-100 $\mathrm{g}$. $/ \mathrm{ml}$., pH 6.2; curve 2 , unheated cells lysed with lysozyme as in curve 1 for 80 min. followed by the addition of crude trypsin ( $1 \mathrm{mg} . / \mathrm{ml}$. final concentration), $\mathrm{pH} \mathrm{6.2;} \mathrm{curve} 3$, heated cells suspended in buffer (pH's 6.2 and $7 \cdot 6$ ) alone; curve 4 , heated cells incubated with $100 \mu \mathrm{g}$. crystalline lysozyme/ml., pH 6.2 ; curve 5, heated cells treated with $100 \mu \mathrm{g}$. crystalline lysozyme/ml. for 80 min. at pH 6.2 (as in curve 1 ) followed by sedimentation of the cells, resuspension in buffer at $\mathrm{pH} 7 \cdot 6$ and incubation with crude trypsin $(1 \mathrm{mg} \cdot / \mathrm{ml}$.); curve 6 , heated cells incubated with crude trypsin-1 $\mathrm{mg} \cdot / \mathrm{ml} ., \mathrm{pH} 7 \cdot 6$.

Streptococcus faecalis. There was no evidence of lysis of unheated suspensions of Strep. faecalis on incubation with crude trypsin $(1 \mathrm{mg} . / \mathrm{ml} ., \mathrm{pH} \mathbf{7 \cdot 6})$ or lysozyme ( $100 \mu \mathrm{g} . / \mathrm{ml} ., \mathrm{pH} \mathrm{6.2)}$ for $2 \mathrm{hr}$. at $37^{\circ}$. Heated cells of this organism showed no lysis on incubation with crude trypsin $(1 \mathrm{mg} . / \mathrm{ml}$.), nor was their turbidity affected by the presence of lysozyme $(100 \mu \mathrm{g} . / \mathrm{ml}$.$) . Repeated$ attempts to detect lysis of heated cells of Strep. faecalis during extended periods of incubation at $37^{\circ}$ with crude trypsin $(1 \mathrm{mg} . / \mathrm{ml}$.) were without success. Indeed, cells autoclaved for $20 \mathrm{~min}$. at $120^{\circ}$, centrifuged and resuspended in phosphate buffer (pH 7.6) were not lysed by crude trypsin (1 mg./ ml.) or crystalline trypsin $\left(100 \mu \mathrm{g} . / \mathrm{ml}\right.$.) on incubation at $37^{\circ}$ for up to $12 \mathrm{hr}$. The resistance of heated Strep. faecalis to digestion with trypsin is similar to that recently reported for group A streptococci by McCarty $(1952 a, b)$. 
Table 2. Enzymic lysis of heated (5 min. at $\left.100^{\circ}\right)$ Staph. aureus suspensions (0.1 M-phosphate buffer, temperature of incubation $\left.37^{\circ}\right)$

\begin{tabular}{|c|c|c|c|}
\hline \multirow[b]{2}{*}{$\begin{array}{l}\text { Time of } \\
\text { incubation } \\
\text { (min.) }\end{array}$} & \multicolumn{3}{|c|}{ Percentage lysis } \\
\hline & $\begin{array}{c}\text { Crude trypsin } \\
(1 \mathrm{mg} \cdot / \mathrm{ml} . ; \mathrm{pH} 7 \cdot 6)\end{array}$ & $\begin{array}{l}\text { Crystalline lysozyme } \\
(100 \mu \mathrm{g} . / \mathrm{ml} . ; \text { pH 6.2) }\end{array}$ & $\begin{array}{c}\text { Pre-treated with } \\
\text { Crystalline lysozyme } \\
(100 \mu \mathrm{g} . / \mathrm{ml} ., \text { pH 6.2 } \\
\text { for } 1 \mathrm{hr} .) \text {; incubated } \\
\text { with crude trypsin } \\
(1 \mathrm{mg} . / \mathrm{ml} ., \mathrm{w} / \mathrm{v} ; \mathrm{pH} 7 \cdot 6)\end{array}$ \\
\hline $\mathbf{5}$ & $\mathbf{2 \cdot 5}$ & $+10 \cdot \gamma^{*}$ & $11 \cdot 4$ \\
\hline 10 & $4 \cdot 9$ & $+10 \cdot 7 *$ & $18 \cdot 2$ \\
\hline 15 & $7 \cdot 4$ & $+10 \cdot 7 *$ & $22 \cdot 7$ \\
\hline 20 & $\mathbf{9} \cdot \mathbf{9}$ & $+10 \cdot 7 *$ & $26 \cdot 1$ \\
\hline $\mathbf{2 5}$ & $12 \cdot 4$ & $+10 \cdot 7 *$ & $\mathbf{2 8} \cdot 6$ \\
\hline $\mathbf{3 0}$ & $13 \cdot 6$ & $+10 \cdot 7 *$ & $30 \cdot 7$ \\
\hline 35 & $14 \cdot 8$ & $+10 \cdot 7 *$ & $\mathbf{3 1 . 5}$ \\
\hline 40 & $16 \cdot 0$ & $+10 \cdot 7^{*}$ & $\mathbf{3 2 \cdot 3}$ \\
\hline 45 & $\mathbf{1 7 \cdot 3}$ & $+10 \cdot 7^{*}$ & $\mathbf{3 3 \cdot 2}$ \\
\hline $\mathbf{5 0}$ & $17 \cdot 3$ & $+10 \cdot 7^{*}$ & 34:1 \\
\hline $\mathbf{5 5}$ & $18 \cdot 5$ & $+10 \cdot 7 *$ & $34 \cdot 8$ \\
\hline 60 & $18 \cdot 5$ & $+10 \cdot 7 *$ & $\mathbf{3 5} \cdot \mathbf{5}$ \\
\hline
\end{tabular}

\section{DISCUSSION}

There can be little doubt that the resistance of living bacteria to digestion by proteolytic enzymes, such as trypsin, is largely due to the nature of their cell walls. The resistance of bacterial cell walls to dissolution by trypsin has been adequately demonstrated by the use of this enzyme in certain stages of the preparation of cell walls (Weidel, 1951; McCarty, 1952 b). The M-protein antigen retained by the cell walls of mechanically disintegrated Strep. pyogenes has been removed with trypsin without affecting the rigidity or appearance of the cell walls (Salton, 1952 $b, 1953$ ). Furthermore, the turbidity of separated cell walls of $\boldsymbol{B}$. megaterium was unaffected by incubation with crude or crystalline trypsin (see Fig. 3).

The complete loss of resistance to lysis with trypsin that Gram-negative bacteria undergo on heating can now be explained in terms of damage to the bacterial cell wall. The walls of Gram-negative bacteria are ruptured on heating (Salton \& Horne, 1951 $a$ ) thereby exposing the coagulated protoplasmic contents of the cell to the direct action of proteolytic enzymes. Earlier work (Kantorowicz, 1909; Tai \& van Heyningen, 1951) showed that Gram-negative bacteria become highly susceptible to tryptic digestion on heating at temperatures of $c .70-80^{\circ}$, and this coincides remarkably well with the temperature range $\left(70-75^{\circ}\right)$ within which cell wall rupture or damage first becomes apparent (Salton \& Horne, 1951 a). In the absence of direct microscopical evidence it might have been argued that heating renders both the cell walls and protoplasmic contents of Gram-negative bacteria susceptible to digestion with trypsin. However, cell walls are the principal trypsinresistant structures found in the residues from heated suspensions of certain 
Gram-negative bacteria that have been lysed with trypsin (see Pl. 1, figs. 1, 2). Salton $(1952 b, 1953)$ found that the cell walls of several Gram-negative bacteria contained considerably more lipid than do any of the walls of Grampositive organisms, and that the cell walls of Gram-negative and Grampositive bacteria differ in their amino-acid constitution. Whether the susceptibility of the cell walls of Gram-negative bacteria to rupture or damage on heating is due to the high lipid content or the nature of the protein component cannot be decided at the moment. A detailed comparison of the constitution of cell walls prepared by heat-treatment rupture or by mechanical disintegration (Salton \& Horne, $1951 b$ ) may provide evidence on this point. It is also conceivable that a melting of the lipid components, instead of actual rupture of the cell walls on heating Gram-negative bacteria, would equally render the coagulated protoplasm vulnerable to digestion with proteolytic enzymes.

There is general agreement that heat-killed Gram-positive organisms are more resistant to lysis with proteolytic enzymes than are heated Gramnegative bacteria. Not all heated Gram-positive bacteria are completely resistant to lysis with crystalline trypsin, e.g. pneumococci studied by Dubos (1987) and certain organisms studied in the present investigation. Although very little or no cell-wall rupture can be detected on heating Gram-positive organisms (Salton \& Horne, $1951 a$; Salton, 1951; and Pl. 1, fig. 4, Pl. 2, fig. 5, of this paper) the cells have been modified sufficiently to allow the penetration of trypsin molecules with subsequent digestion of the coagulated protoplasmic contents (see Pl. 2, figs. 7, 8). The greater resistance of heat-killed Grampositive bacteria to trypsin lysis does not appear to be a property of the coagulated protoplasm of these organisms, for it has been adequately demonstrated that enzymic degradation of the cell walls of heated bacteria greatly facilitates tryptic digestion. It is clear, therefore, that the resistance of heated Gram-positive bacteria to digestion by proteolytic enzymes is largely governed by the nature of the cell walls.

The evidence presented in this paper illustrates the unsuitability of heated bacterial cells as a substrate for the detection of enzymes which decompose cell walls. Extensive lysis of heated Gram-negative bacteria can be effected with the proteolytic enzyme, trypsin, without dissolution of the cell walls. The unsuitability of using heat-killed bacteria for the detection of enzymes which degrade cell walls is further shown by the action of lysozyme on heated $B$. megaterium. There is abundant evidence that enzymic lysis of suspensions of living organisms is correlated with the dissolution of the separated cell walls by the lytic enzyme. However, the production of lytic zones by the growth of soil micro-organisms on nutrient agar inoculated with living bacteria may well be the result of the combined action of bactericidal substances and of proteolytic enzymes. The isolation of micro-organisms which produce lytic zones on agar containing sufficient quantities of separated cell walls to give an opaque medium, would appear to offer favourable conditions for the selection of organisms capable of producing cell-wall decomposing enzymes. 
I should like to express my thanks to Merck \& Co. Inc., for the award of the Merck International Fellowship, and to Prof. R. Y. Stanier for his generous hospitality and interest in the investigations. I am most grateful to Dr Robley C. Williams for the preparation of the electron micrographs.

\section{REFERENCES}

Bons, G. V. R. (1952). The extracellular bacteriolytic enzymes of a species of Streptomyces. J. gen. Microbiol. 6, 344.

Dusos, R. J. (1937). The autolytic system of pneumococci. J. exp. Med. 65, 873.

Dubos, R. J. \& Avery, O. T. (1931). Decomposition of the capsular polysaccharide of pneumococcus type III by a bacterial enzyme. J. exp. Med. 54, 51 .

Epstein, L. A. \& Chain, E. (1940). Some observations on the preparation and properties of the substrate of lysozyme. Brit. J. exp. Path. 21, 339.

Fremrng, A. (1922). On a remarkable bacteriolytic element found in tissues and secretions. Proc. roy. Soc. B, 93, 306.

Jones, A. S., Swallow, A. J. \& WeBB, M. (1948). The exocellular bacteriolytic system of soil actinomyces. 1 . The nature and properties of the lytic system. Biochim. biophys. Acta, $2,167$.

Kantorowicz, A. (1909). Bakterien-Antifermente und Bakteriolyse. Münch. med. Wschr. 56, 897.

LANCEFIELD, R. C. (1943). Studies on the antigenic composition of group A hemolytic streptococci. J. exp. Med. 78, 465.

MaXted, W. R. (1948). Preparation of streptococcal extracts for Lancefield grouping. Lancet, ii, 255.

MCCARTY, M. (1952 $a)$. The lysis of group A hemolytic streptococei by extracellular enzymes of Streptomyces albus. I. Production and fractionation of the lytic enzymes. J. exp. Med. 96, 555.

MCCARTY, M. (1952b). The lysis of group A hemolytic streptococci by extracellular enzymes of Streptomyces albus. II. Nature of the cellular substrate attacked by the lytic enzymes. J. exp. Med. 96, 569.

Mugacton, P. W. \& WeBs, M. (1952). The exocellular bacteriolytic system of soil actinomyces. II. A further investigation of the lytic system. Biochim. biophys. Acta, 8, 431.

Salton, M. R. J. (1951). Some properties of the bacterial cell envelope. Thesis: University of Cambridge.

Salton, M. R. J. (1952a). Cell wall of Micrococcus lysodeikticus as the substrate of lysozyme. Nature, Lond. 170, 746.

Salton, M. R. J. (1952b). The nature of the cell walls of some Gram-positive and Gram-negative bacteria. Biochim. biophys. Acta, 9, 334.

Salton, M. R. J. (1953). Studies of the bacterial cell wall. IV. The composition of the cell walls of some Gram-positive and Gram-negative bacteria. Biochim. biophys. Acta, 10, 512.

Salton, M. R. J. \& Horne, R. W. (1951a). Studies of the bacterial cell wall. I. Electron microscopical observations on heated bacteria. Biochim. biophys. Acta 7, 19.

Salton, M. R. J. \& Horne, R. W. (1951 b). Studies of the bacterial cell wall. II. Methods of preparation and some properties of cell walls. Biochim. biophys. Acta, 7, $17 \%$.

TAX, T. Y. \& van HeYningen, W. E. (1951). Bacteriolysis by a species of Streptomyces. J. gen. Microbiol. $5,110$.

Thompson, R. (1940). Lysozyme and its relation to antibacterial properties of various tissues and secretions. Arch. Path. 30, 1096.

Waksman, S. A. (1947). Microbial Antagonism and Antibiotic Substances, 2nd ed. New York: The Commonwealth Fund. 
Journal of General Microbiology, Vol. 9, No. 3
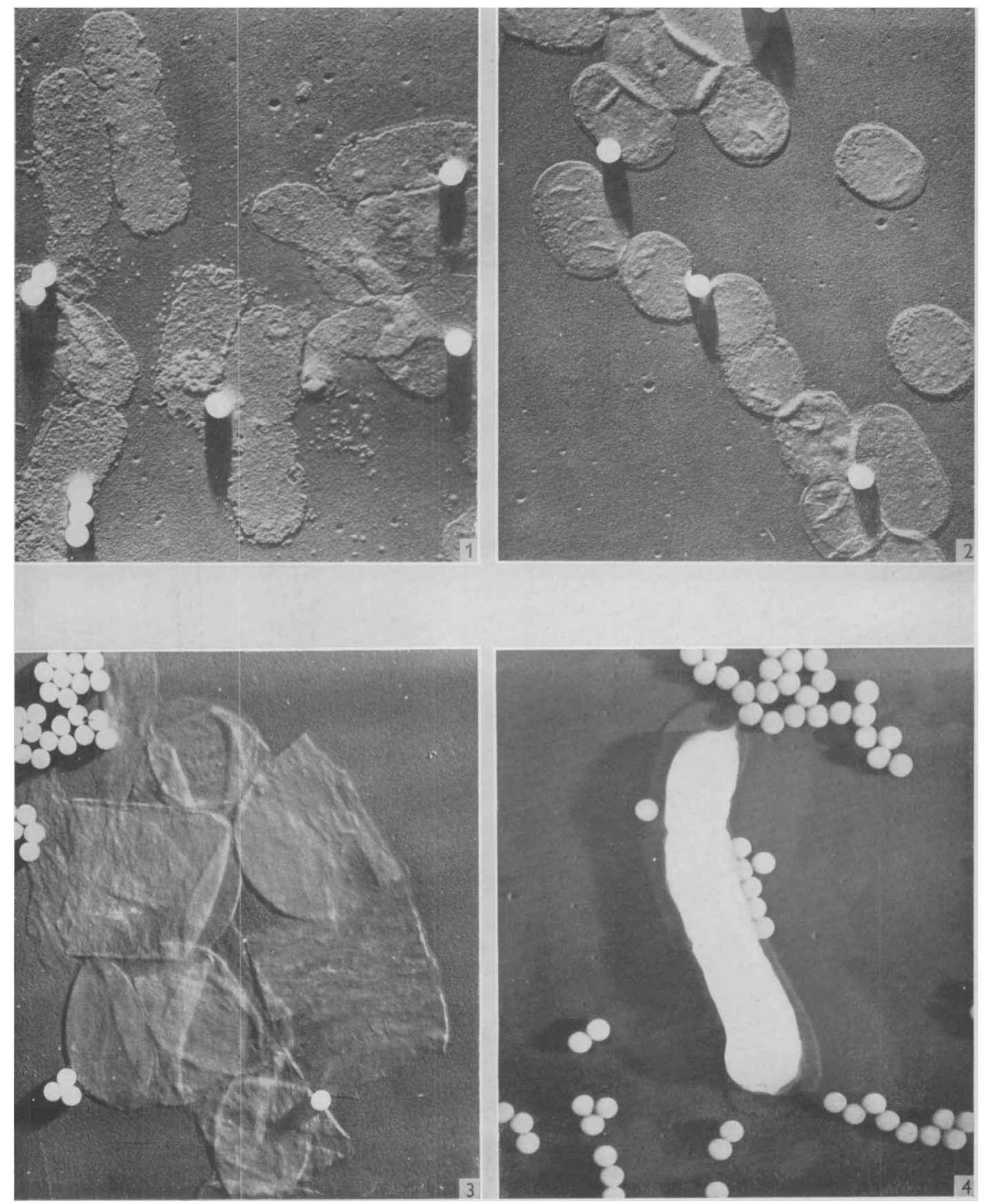

M. R. J. Salton-Enzy hic lysis of bacteria. Plate 1 
Journal of General Microbiology, Vol. 9, No. 3
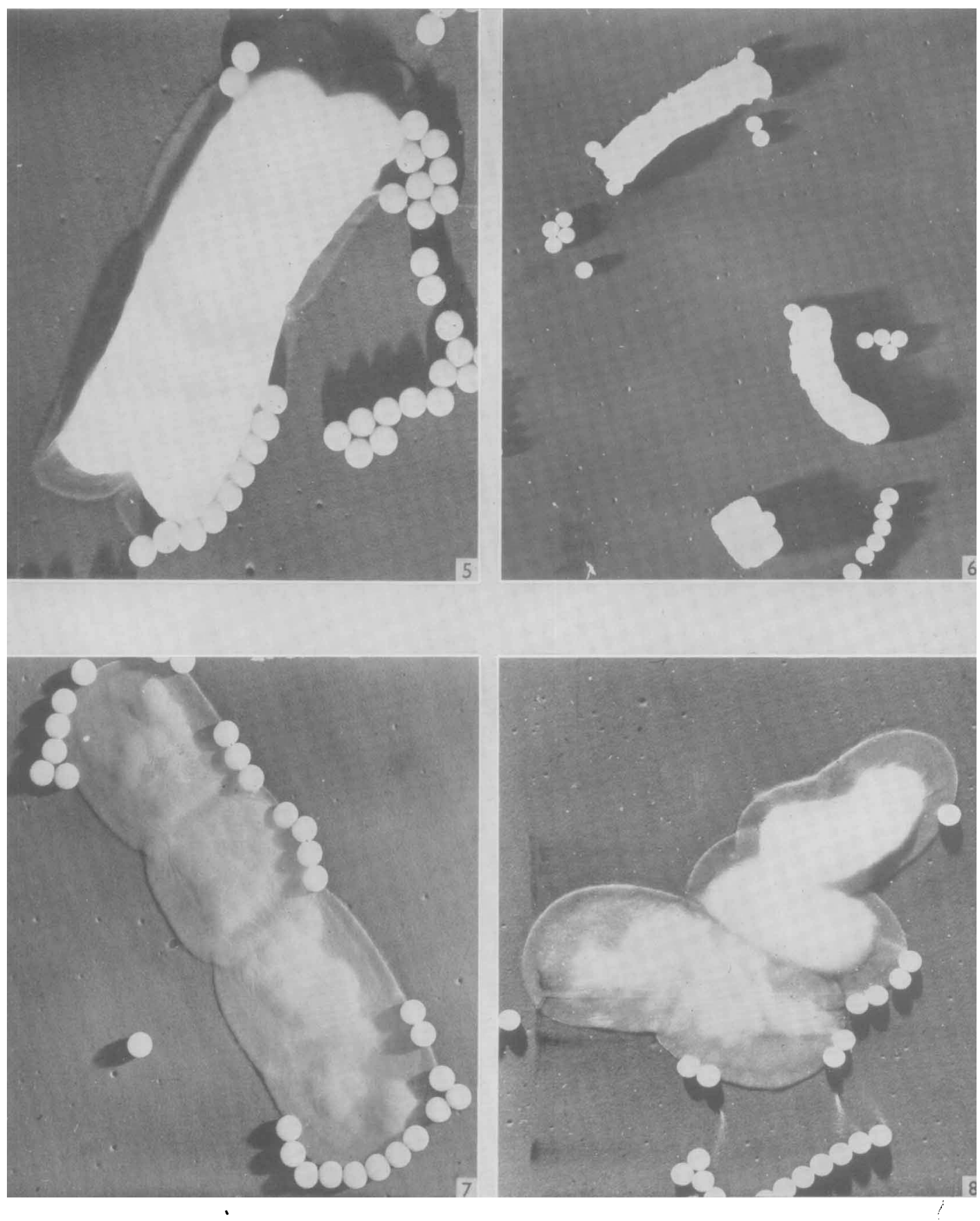

M. R. J. Salton-Enzymic lysis of bacteria. Plate 2 
WabB, M. (1948). The action of lysozyme on heat-killed Gram-positive microorganisms. J. gen. Microbiol. 2, 260.

Wemex, W. (1951). Utber die Zellmembran von Escherichia coli B. Z. Naturf. 6b, 251.

WrLscr, M. (1947). Phénomènes d'antibiose chez les Actinomycètes. Gembloux: Imprimerie J. Duculet.

Welshimer, H. J. \& RoBinow, C. F. (1949). The lysis of Bacillus megatherium by lysozyme. J. Bact. $57,489$.

\section{EXPLANATION OF PLATES}

All photographs are electron micrographs of preparations shadowed with uranium. The electron-dense spheres are polystyrene latex indicator particles.

\section{Plate 1}

Fig. 1. Residue from suspension of heat-killed Bact. coli lysed with crude trypsin (1 mg./ml.) for $2 \mathrm{hr}$. at $87^{\circ}$. $\times 15,000$.

Fig. 2. Residue from suspension of heat-killed Ps. fluorescens lysed with crude trypsin (1 mg./ml.) for $2 \mathrm{hr}$. at $37^{\circ}$. $\times 15,000$.

Fig. 3. B. megaterium cell-wall preparation. $\times 12,000$.

Fig. 4. Heat-killed B. megaterium cell. $\times 13,000$.

\section{Prate 2}

Fig. 5. Heat-killed $B$. megaterium cells. $\times 17,000$.

Fig. 6. Heated $B$. megaterium cells treated with crystalline lysozyme $(100 \mu \mathrm{g}$. $/ \mathrm{ml}$.) for 60 min. at $37^{\circ}$. Note the complete removal of the cell wall by enzymic digestion. $\times 10,000$.

Figs. 7,8 . Showing the appearance of heated cells of $B$. megaterium after incubation with crude trypsin (1 mg./ml.) for $2 \mathrm{hr}$. at $37^{\circ}$. Compare with heated cells in figs. 4 and 5. Fig. $7, \times 16,000$; fig. $8, \times 13,000$.

(Received 22 June 1953) 